\title{
IN VITRO SOLUBILITY OF MEAT AND BONE MEAL PROTEIN WITH DIFFERENT PEPSIN CONCENTRATIONS
}

\author{
SOLUBILIDADE IN VITRO DA PROTEÍNA DE FARINHAS DE CARNE E OSSOS \\ COM DIFERENTES CONCENTRAÇOES DE PEPSINA
}

\author{
Cláudio Bellaver ${ }^{1}$ Dirceu Luís Zanotto ${ }^{2}$ Antônio Lourenço Guidoni ${ }^{3}$ \\ Claudete Hara Klein ${ }^{4}$
}

\section{RESUMO}

\begin{abstract}
A digestibilidade in vitro da proteína de fontes protéicas tem sido correlacionada com a digestibilidade in vivo. Entretanto, fatores como a origem protéica, enzima usada e sua concentração, $\mathrm{pH}$ e processamento têm sido relacionados com a significância da correlação entre as estimativas. Para atuar somente no fator da concentração enzimática, este trabalho teve por objetivo testar a pepsina nas concentrações de 0,2, 0,02, 0,002 e 0,0002\%, utilizando o procedimento padrão do AOAC (1995). Duas farinhas de carne e ossos com baixo ou alto teor de proteína (PB) foram usadas para determinar o coeficiente de solubilidade da PB em pepsina e $\mathrm{HCl}$ (CSCPPEPH). Centrifugação foi usada para obter o nitrogênio $(N)$ na fase solúvel, em vez da filtração e análise do $N$ no resíduo não filtrado. Foi conduzida uma análise de variância e o modelo não linear assintótico foi ajustado aos dados. A variável CSCPPEPH em diferentes concentrações de pepsina, para as duas farinhas de carne e ossos, mostrou maior discriminação da solubilidade com baixa concentração de pepsina. O nível de 0,0002\% de pepsina é melhor preditor da PB solúvel nas farinhas de carne e ossos. Os resultados obtidos permitem assumir que a concentração de $0,2 \%$, definida pelo AOAC, não é correta para o propósito de determinar o intervalo de solubilidade em farinhas de carne e ossos de alta e baixa $P B$.
\end{abstract}

Palavras-chave: digestão, subprodutos de origem animal, metodologias in vitro.

\section{SUMMARY}

In vitro protein digestibility of protein sources has been correlated with in vivo digestibility values. However, factors like protein origin, enzyme used and its concentration, $\mathrm{pH}$ and processing have been related with the significance of the correlation between the estimates. To address only the enzyme concentration factor, this paper had the objective of testing pepsin at 0.2, 0.02, 0.002 and $0.0002 \%$ using the standard $A O A C$ (1995) procedure. Two meat and bone meals (MBM) with low and high crude protein $(\mathrm{CP})$ content were used to determine the coefficient of solubility of $\mathrm{CP}$ in pepsin and $\mathrm{HCl}$ (CSCPPEPH). Centrifugation was used to establish the nitrogen $(N)$ in the soluble phase, instead of filtration and analysis of $N$ in the residue. The variance analysis and a non-linear asymptotic model were adjusted. The CSCPPEPH under different pepsin concentrations for the two MBM showed higher solubility discrimination with low pepsin concentration. The level of $0.0002 \%$ pepsin is better to predict the CP soluble in MBM. This finding implies the assumption that $0.2 \%$ pepsin found in the $A O A C$ is not correct for the purpose of determining the range of solubility in high and low CP content in MBM.

Key words: digestion, animal by-product, in vitro methodology.

\section{INTRODUCTION}

The in vitro protein solubility has been tested to estimate the in vivo digestibility (BELLAVER et al., 1991; HAN, 1990). However, factors like protein source (CAVE, 1988), enzymatic concentration (JOHNSTON \& COON, 1979; PARSONS et al., 1997), enzyme used and $\mathrm{pH}$ (CONE, 1993) and processing (ZOMBADE \& SATHE, 1977) have been related with the significance of the correlation between in vivo and

\footnotetext{
${ }^{1}$ Médico Veterinário, PhD., Embrapa Suínos e Aves , CP 21, 89700-000, Concórdia, SC. E-mail: bellaver@cnpsa.embrapa.br. Author for correspondence.

${ }^{2}$ Biólogo, MSc., Embrapa Suínos e Aves.

${ }^{3}$ Engenheiro Agrônomo, MSc., Embrapa Suínos e Aves.

${ }^{4}$ Zootecnista, MSc., Embrapa Suínos e Aves.
} 
in vitro. The in vitro digestibility technique of products from animal origin was developed between 1950 and 1975 and the final form of the method described by AOAC (1995). Many nutrition laboratories around the world use the AOAC method, an example being the laboratory reference book issued by the feed industry in Brazil (BRAZIL, 1998). A deeper look into the technique shows it has little value in estimating digestibility of proteins of animal origin. Therefore, we suggest that solubility be used in substitution for digestibility, since it is more related with what occurs in vivo. Another important point is that much time is involved when using filtration and crude protein $(\mathrm{CP})$ analysis of the undigested residue. Time for running the analysis can be optimized without loss of precision by using centrifugation and analyzing $\mathrm{CP}$ in the supernatant. Therefore, the objective of this work was to improve the methodology by using a proper pepsin concentration. Two types of meat and bone meals (MBM) were used to determine CP solubility by centrifugation to determine the nitrogen $(\mathrm{N})$ in the soluble phase.

\section{MATERIAL AND METHODS}

The basic methodology used to determine solubility of $\mathrm{CP}(\mathrm{N} \times 6.25)$ in this work is that reported by the AOAC (1995). However, few modifications were incorporated into this procedure. The enzyme concentration was the main objective of this paper, and the values tested ranged from $0.2 \%$ to $0.0002 \%$ in 10 fold increments. Similar concentrations were also used by PARSONS et al. (1997) working with MBM. In addition, soluble CP was obtained from the supernatant after centrifugation at $2500 \mathrm{rpm}$ for $15 \mathrm{~min}$. The sample agitator indicated by AOAC (1995) was substituted by a similar one made locally. The tested hypothesis was that lower pepsin concentrations than the $0.2 \%$ recommended by AOAC (1995) are better to discriminate in vitro quality of meat and bone meals (MBM). An experiment was carried out with two MBM. One of them was a high $(\mathrm{H}=$ $57.66 \%)$ and the other a low $(\mathrm{L}=38.79 \%) \mathrm{CP}$. The tested pepsin (Sigma P 7000, 1:10,000 activity) concentrations were $0.0002,0.002$, 0.02 and $0.2 \%$. The variables studied were the percent $(\%)$ of $\mathrm{CP}$ soluble in the pepsin solution (CPSOL); the solubility coefficient of CP in one of the pepsin concentrations (CSCPPEP) and the coefficient of solubility in pepsin plus $\mathrm{HCl}$ at $0.0744 \mathrm{~N}$ (CSCPPEPH). The statistical analysis considered a factorial structure with 2 MBM types and 4 enzyme concentrations, with 4 replications per treatment. Simultaneously, eight samples digested with $\mathrm{HCl} 0.0744 \mathrm{~N}$ were used as blanks and allow correction for pepsin solubility alone. Variance analysis and non-linear logistic, exponential and asymptotic Spillman models described by HOFFMAN \& VIEIRA (1987) were calculated with collected data using SAS computer package. The general Spillmann equation is: $\mathrm{Y}=\mathrm{A}\left(1-10^{-\mathrm{C}(\mathrm{X}+\mathrm{B})}\right)$, where: $\mathrm{A}=$ maximum response value when the concentration increases unrestrained; $\mathrm{B}=\mathrm{a}$ parameter that determines the response when pepsin concentration is equal to zero; $\mathrm{C}=$ the velocity of response increment and $\mathrm{X}=$ the pepsin concentration in percentage.

\section{RESULTS AND DISCUSSION}

The results of in vitro $\mathrm{CP}$ solubilization are presented in table 1 . The analysis of variance revealed a significant $(\mathrm{P}<0.0001)$ interaction between MBM and pepsin concentrations. Thus, the three variables studied were analyzed within MBM and the equations are shown in table 2. The estimates of CP solubility for each MBM, as well as the interval (distance between estimates) are presented in table 3 and in figures 1 and 2.

Tablle 1 - Crude protein (CP) solubility in meat and bone meals with different concentrations of pepsin and (or) $\mathrm{HCl}$.

\begin{tabular}{|c|c|c|c|c|c|c|c|c|}
\hline \multirow[t]{2}{*}{$\mathrm{MBM}^{1}$} & \multirow[t]{2}{*}{ Pepsin (\%) } & \multirow[t]{2}{*}{$\mathrm{n}$} & \multicolumn{2}{|c|}{$\mathrm{CPSOL}^{2}$} & \multicolumn{2}{|c|}{ CSCPPEP $^{3}$} & \multicolumn{2}{|c|}{ CSCPPEPH $^{4}$} \\
\hline & & & Avg. & SEM & Avg. & SEM & Avg. & SEM \\
\hline Low & 0.2 & 4 & 43.76 & 0.39 & 92.02 & 1.26 & 93.48 & 1.01 \\
\hline Low & 0.02 & 4 & 35.05 & 0.69 & 85.81 & 2.17 & 88.42 & 1.79 \\
\hline Low & 0.002 & 4 & 25.40 & 0.34 & 57.50 & 1.04 & 65.30 & 0.87 \\
\hline Low & 0.0002 & 4 & 13.10 & 0.30 & 18.86 & 1.25 & 33.76 & 0.78 \\
\hline High & 0.2 & 4 & 61.14 & 0.48 & 85.17 & 1.43 & 93.02 & 0.84 \\
\hline High & 0.02 & 4 & 53.17 & 0.38 & 80.64 & 1.28 & 90.91 & 0.66 \\
\hline High & 0.002 & 4 & 50.27 & 1.35 & 72.40 & 5.31 & 87.05 & 2.34 \\
\hline High & 0.0002 & 4 & 45.37 & 0.77 & 54.60 & 2.67 & 78.68 & 1.35 \\
\hline \multicolumn{3}{|c|}{ Average } & \multicolumn{2}{|c|}{40.91} & \multicolumn{2}{|c|}{68.37} & \multicolumn{2}{|c|}{78.83} \\
\hline \multicolumn{3}{|c|}{ Coef. of Determination } & \multicolumn{2}{|c|}{0.99} & \multicolumn{2}{|c|}{0.99} & \multicolumn{2}{|c|}{0.99} \\
\hline \multicolumn{3}{|c|}{ Coef. of Variation } & \multicolumn{2}{|c|}{1.65} & \multicolumn{2}{|c|}{3.58} & \multicolumn{2}{|c|}{1.68} \\
\hline
\end{tabular}

${ }^{1}$ Types of meat and bone meals with low $(38.79 \%)$ and high $(57.66 \%)$ crude protein;

${ }^{2}$ Soluble CP $(\%)$

${ }^{3}$ Coefficient of solubility for CP in Pepsin (\%);

${ }^{4}$ Coefficient of solubility for $\mathrm{CP}$ in pepsin and $\mathrm{HCl}(\%)$. 
Table 2 - Parameter for the regression equations to estimate the crude protein $(\mathrm{CP})$ solubility in meat and bone meal with different concentrations of pepsin ${ }^{1}$.

\begin{tabular}{|c|c|c|c|c|c|}
\hline Variable & $\mathrm{MBM}^{2}$ & A & B & $\mathrm{C}$ & Correlation \\
\hline $\mathrm{CPSOL}^{3}$ & $\mathrm{~L}$ & 43.13 & 0.00703 & 30.6 & 0,95 \\
\hline CPSOL & $\mathrm{H}$ & 61.13 & 0.04906 & 13.1 & 0,96 \\
\hline CSCPPEP $^{4}$ & $\mathrm{~L}$ & 88.92 & 0.00034 & 193.3 & 0,99 \\
\hline CSCPPEP & $\mathrm{H}$ & 82.91 & 0.00175 & 239.2 & 0,97 \\
\hline CSCPPEPH $^{5}$ & $\mathrm{~L}$ & 90.96 & 0.00084 & 193.3 & 0,99 \\
\hline CSCPPEPH & $\mathrm{H}$ & 91.97 & 0.00330 & 239.9 & 0,97 \\
\hline
\end{tabular}

${ }^{1}$ General asymptotic model $\mathrm{Y}=\mathrm{A}\left(1-10^{-\mathrm{C}(\mathrm{X}+\mathrm{B})}\right)$; where $\mathrm{X}$ is the pepsin concentration $(\%) ; \mathrm{A}=$ maximum response value when the concentration increases unrestrained; $\mathrm{B}=\mathrm{a}$ parameter that determines the response when pepsin concentration is equal to zero and $\mathrm{C}=$ the velocity of response increment.

${ }^{2}$ Meat and bone meals of low $(\mathrm{L}=38.79 \%)$ and high $(\mathrm{H}=$ $57.66 \%)$ crude protein content;

${ }^{3}$ Soluble CP $(\%)$;

${ }^{4}$ Coefficient of solubility for CP in Pepsin (\%);

${ }^{5}$ Coefficient of solubility for $\mathrm{CP}$ in pepsin and $\mathrm{HCl}(\%)$.

Recently, pepsin concentrations of $0.0002 \%$ or $0.2 \%$ were tested by PARSONS et al. (1987) for nitrogen digestibility. They calculated correlations of 0.70 and 0.40 respectively when relating pepsin nitrogen digestibility and lysine digestibility percentages in roosters. Previously JOHNSTON \& COON (1979) also working with different pepsin concentrations found an increament in the range of solubility by decreasing the pepsin concentration. However, these authors did not work on a concentration higher than $0.002 \%$ of pepsin. Therefore, decrease the enzyme concentration seems to be important to increase the range of solubility and get advantage of better solubility range discrimination.

In the present study, although the logistic and exponential models permit fitting the solubility of CP within the interval studied, showing $\mathrm{R}^{2}$ greater than 0.90, they do not fit the Michaelis-Menten (MURRAY et al., 1996) equation when over $0.2 \%$ of pepsin is used. Therefore, the asymptotic model was adopted, since it fits the data precisely in any pepsin concentration. HOFFMAN \& VIEIRA (1987) described the mathematics behind the model. Table 1 shows that all the variable expressions used for CP solubility presented a good fit to the variance analysis with high $\mathrm{R}^{2}$ and low coefficients of variation. MBM with low $\mathrm{CP}$ presented a greater drop in $\mathrm{CP}$ solubility when comparing the end of enzymatic concentrations than the MBM with high CP. The estimates for parameter A (Table 2) indicate
Table 3 - Solubility estimates for crude protein (CP) measured by $\mathrm{CPSOL}^{1}, \mathrm{CSCPPEP}^{2}$ and $\mathrm{CSCPPEPH}^{3}$ for two meat and bone meals with different enzyme concentration calculated by the asymptotic model.

\begin{tabular}{|c|c|c|c|c|}
\hline Variable & Pepsin $(\%)$ & Low CP MBM & High CP MBM & Difference \\
\hline CPSOL & $\begin{array}{l}0.00002 \\
0.0002 \\
0.002 \\
0.02 \\
0.2\end{array}$ & $\begin{array}{l}16.87 \\
17.20 \\
20.29 \\
36.70 \\
43.13\end{array}$ & $\begin{array}{l}47.22 \\
47.30 \\
48.03 \\
53.52 \\
61.10\end{array}$ & $\begin{array}{l}30.35 \\
30.10 \\
27.74 \\
16.82 \\
17.97\end{array}$ \\
\hline CSCPPEP & $\begin{array}{l}0.00002 \\
0.0002 \\
0.002 \\
0.02 \\
0.2\end{array}$ & $\begin{array}{l}13.01 \\
18.86 \\
57.48 \\
88.91 \\
88.92\end{array}$ & $\begin{array}{l}51.65 \\
54.60 \\
72.40 \\
82.91 \\
82.91\end{array}$ & $\begin{array}{l}38.63 \\
35.74 \\
14.92 \\
-6.00 \\
-6.01\end{array}$ \\
\hline CSCPPEPH & $\begin{array}{l}0.00002 \\
0.0002 \\
0.002 \\
0.02 \\
0.2\end{array}$ & $\begin{array}{l}28.99 \\
33.76 \\
65.29 \\
90.95 \\
90.96\end{array}$ & $\begin{array}{l}77.29 \\
78.68 \\
87.05 \\
91.97 \\
91.97\end{array}$ & $\begin{array}{r}48.30 \\
44.92 \\
21.76 \\
1.02 \\
1.01\end{array}$ \\
\hline
\end{tabular}

${ }^{1}$ Soluble CP;

${ }^{2}$ Coefficient of solubility for CP in Pepsin;

${ }^{3}$ Coefficient of solubility for $\mathrm{CP}$ in pepsin and $\mathrm{HCl}$.

that the CSCPPEPH is above $90 \%$ in higher enzymatic concentrations. In addition, the coefficient of variation for this variable is lower (table 1), making it the best to interpret CP solubility in pepsin. Crude protein solubility estimates for CPSOL, CSCPPEP and CSCPPEPH under different pepsin concentrations for the two MBM (Table 3) show higher solubility discrimination with low pepsin concentrations. This is also demonstrated in figures 1 (real values) and 2 (log scale), which show a better discrimination for the lower pepsin

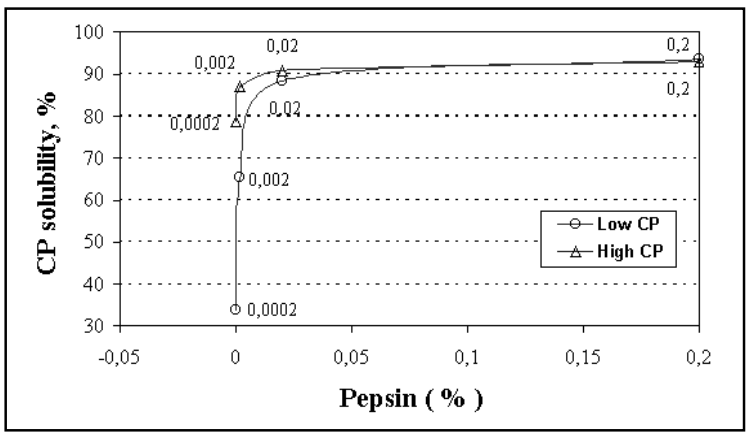

Figure 1 - Crude protein solubility of meat and bone meal with high and low crude protein content digested under different pepsin concentrations. 


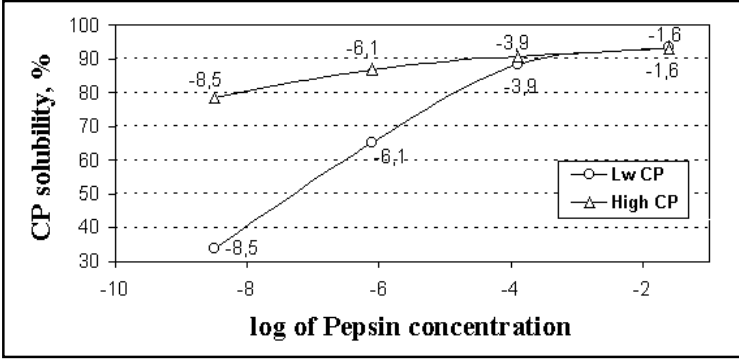

Figure 2 - Crude protein solubility of meat and bone meal with high and low crude protein content digested under different pepsin concentrations on the log scale.

concentrations. The $0.0002 \%$ level is the best predictor for the CP soluble in MBM. In addition, it could be advantageous to decrease the concentration to $0.00002 \%$ of pepsin, as indicated by the asymptotic model, to discriminate the quality of meat and bone meals. This finding implies that the levels of $0.2 \%$ pepsin in AOAC (1995) or $0.02 \%$ in BRAZIL (1998) are not correct for the purpose of determining e the range of solubility in high and low $\mathrm{CP}$ content in MBM.

\section{CONCLUSIONS}

The indicated concentration of pepsin to obtain the solubility of crude protein in different meat and bone meals is $0.0002 \%$. The best variable to express the protein solubility is the coefficient of solubility of crude protein in pepsin and $\mathrm{HCl}$ solution.

\section{ACKNOWLEDGEMENTS}

The authors would like to thank the Brazilian National Council for Research $(\mathrm{CNPq})$ for the financial support for this study.

\section{REFERENCES}

ASSOCIATION OF OFFICIAL ANALITICAL CHEMISTS (AOAC). Pepsin digestibility of animal protein feeds. In: OFFICIAL METHODS OF ANALYSIS OF AOAC INTERNATIONAL $16^{\mathrm{TH}}$ ED. Arlington, Virginia : Patricia Cunniff, 1995. Cap.4. p.15-16.

BELlAVER, C., EASTER, R.A., COOK, D.A., et al. A comparison of in vivo and in vitro methods for estimating digestibility in swine. In: INTERNATIONAL SYMPOSIUM ON DIGESTIVE PHYSIOLOGY IN PIGS, 5, 1991, Wageningen. Proceedings... Wageningen : Centre for Agricultural publishing and Documentation (Puddock), 1991. 481p. p. 241-247.

BRAZIL. Ministério da Agricultura e do Abastecimento. Compêndio brasileiro de alimentação animal: métodos analíticos. Digestibilidade em pepsina. Brasília : Secretaria Executiva Sindirações / ANFAR, 1998. p.147-149.

CAVE, N.A. Bioavailability of amino acids in plant feedstuffs determined by in vitro digestion, chick growth assay and the amino acid availability methods. Poultry Science v.67, p.7887, 1988.

CONE, J.W. The influence of $\mathrm{pH}$ on in vitro protein solubility and enzymatic hydrolysis of protein in feedstuffs. J Animal Feed Science v.2, p.67-72. 1993.

HAN, Y. Evaluation of methodology for determination of availability of amino acids and energy in feedstuffs for poultry. Champaign, Urbana, 1990. 115p. Thesis (Animal Sciences PhD) - University of Illinois, 1990.

HOFFMAN, R., VIEIRA, S. Análise de regressão. Uma introdução a econometria. São Paulo : Hucitec, 1987. 379p.

JOHNSTON, J., COON, C.N. The use of varying levels of pepsin for pepsin digestion studies with animal proteins. Poultry Science v.58, p.1271-1273. 1979.

MURRAY, K.R., GRANNER D.K., MAYES, P.A., $\boldsymbol{e}$ t al. Harper's Biochemistry. $24^{\text {th }}$ ed. Stamford, CT : Appleton \& Lange, 1996. 868p.

PARSONS, C.M., CASTANON, F., HAN, Y. Protein and amino acid quality of meat and bone meal. Poultry Science v.76, p.361-368. 1997.

ZOMBADE, S.S., SATHE, B.S. The relative value of different laboratory tests to detect nutritive loss due to heat treatment. Indian J Nutrition Dietetics. v.14, p.203-204. 1977.

Ciência Rural, v. 30, n. 3, 2000. 